\title{
Integration of Immigrants in Sweden 1945-1975
}

\author{
DANIEL RAUHUT, Ph.D. (Economic History), University Lecturer \\ School of Health and Society, University of Malmö, Sweden
}

\begin{abstract}
Over the past 30 years the relative incomes and employment rates of immigrants have sunk, while immigrants' unemployment rates rose. The overrepresentation in the welfare transfer system and an increasing housing segregation cause concern and is much debated. The general opinion is that immigrants are less integrated into the Swedish society today than in former times. The aim of this literature review is to if this is true. The working hypothesis is that immigrants were integrated during the period 1945-1975. A set of nine variables are discussed to examine whether the immigrants 1945-1975 were integrated.

Although explorative by its character, the results indicate that immigrants were not as integrated in former times as commonly believed. Contrary to common belief significant improvements in integration has, in some areas, actually been achieved! The integration of immigrants has not changed from good to bad, but rather from bad to worse.
\end{abstract}

Keywords: Integration, immigrants, labour market, incomes, social networks

\section{Introduction}

Over the past 30 years the relative incomes and employment rates of immigrants have sunk, while immigrants' unemployment rates rose. The overrepresentation in the welfare transfer system and an increasing housing segregation has caused concern and is much debated. The general opinion is that immigrants are less integrated into the Swedish society today than in former times regardless if immigrants are seen as nonSwedish citizens or foreign born persons (Björklund et al. 1998; Socialdepartementet 2001; Lundh et al. 2002; Lundh 2005; Åslund et al. 2006).

The relative employment rate for immigrant men has dropped from 98 percent of the native men in 1975 to 80 percent in 2003 , while the relative employment rate for immigrant women has dropped from 102 percent of the native women in 1975 to 75 percent in 2003. The relative incomes of immigrants follow the same trend as the relative employment rate since 1978. In 1978 the relative income of immigrants in Sweden was 99 percent of the natives' income, but in 2002 the relative income was down to 
67 percent (Ekberg 2006, 148). The relative unemployment rate has increased more or all immigrant groups in Sweden relative the natives since the early 1990s. Not only the relative unemployment rate has increased for immigrants since the early 1990s, the duration of unemployment has increased and the share on short-term contracts has increased more for immigrants than for the natives during the 1990s (SCB 2002, $88-91)$.

The share of immigrants amongst the recipients of economic assistance has increased since the early 1990s. Beaten by single mothers and youngsters $18-24$, the third highest relative risk for becoming dependent on economic assistance is shown by non-OECD immigrants and they also show the lowest relative risk to support themselves again. Furthermore, they also show longer duration of dependency on economic assistance (Dahlberg et al. 2008, 32-42). The recipients of economic assistance are marginalised, not only at the labour market but in society in general. They show, besides weak economic situation and labour market attachment, also a weaker health, political poverty ${ }^{1}$ and small social networks. As immigrants are overrepresented amongst the recipients of economic assistance the situation calls for concern; being dependent on economic assistance is an indicator of being excluded from society in general and immigrants have increased their share amongst the recipients of economic assistance over time (Franzén 2004, 125-).

The general health status of the Swedish population has improved since the mid-1970s up to the 1990s, when the effects of the economic crisis affected the population in the form of unemployment, cut-backs in the welfare systems etc. Still, the immigrant population shows a higher share of e.g. perceived illness, chronic diseases, reduced work capability and psychological well-being than the native population (SCB 2002, 133-140). For the period 1981-1999 immigrants, both men and women, have a significantly higher rate of early retirement than the native population (Gustafsson and Östberg 2004, 83).

Despite the political ambitions since the 1970s to decrease the ethnical housing segregation in Sweden it has in fact increased at the turn of the millennium (Molina 2000, 140). Other researchers points out that the housing segregation of today was founded in the 1970s. It has both ethnical and socioeconomic aspects, which, in turn, are interrelated (Andersson 2000, 255-257.). Immigrants also live in apartments to a higher extent than natives and have a higher restriction for space and overcrowding in their housing than natives (Häll 1998, 479-81). Furthermore, immigrants have weaker social networks and weaker political resources than the natives. The gap between immigrants and natives regarding these aspects has remained unchanged between the early and late

1 Here political poverty refers to being excluded from decision making and being unable to protect ones basic civil rights. e.g. writing a letter to the authorities or report that a crime has been committed against you. 
1990s (Socialdepartementet 2001, 79-). Differences in leisure and material standard indicate economic differences between immigrants and natives (Häll 1998, 481-83).

While many labour market immigrants during the 1950s, 1960s and the first half of the 1970s settled down in industrial towns or communities as a result of the demand of blue-collar workers, the refugees after the 1970s and 1980s became more concentrated to the metropolitan areas - the Stockholm, Göteborg and Malmö regions - and very unwilling to leave these areas (Johansson and Rauhut 2008, 40).

The integration of immigrants in Sweden over the past 30 years is no encouraging reading. Despite all political ambitions of the Swedish welfare state something appears to have gone wrong when it comes to the integration of immigrants. This perception is however based upon the assumption that integration was good in former times.

Since the employment rates and relative incomes of immigrants were higher than for natives, the general opinion appears to be that immigrants were better integrated in the 1950s and 1960s, which is advocated by Lundh and Ohlsson $(1994,65)$ and Ekberg $(2006,146)$. Lundh $(2005,61-63)$ states that the labour immigrants and refugees were well-integrated in the Swedish labour market until 1970, but not after. Hence, integration is solely related to employment and income. Some objections against this are raised. Svanberg and Tydén (1992, 333-35) argue that the problems related to labour immigrants and refugees were considered as merely a language issue by the Swedish authorities until the early 1960 s.

The aim of this study is to analyse if immigrants were integrated into the Swedish society during the period 1945-1975, which was the era of labour immigration to Sweden. Two questions are proposed to be answered: (1) were there any significant differences between immigrants and natives concerning labour market behaviour and socio-cultural activities, and (2) to what extent, if any significant differences are identified, can these differences be related to the integration issue? Since the topic for this study is huge, the study is tentative by its character.

\section{Definitions}

Most definitions of what an immigrant is are based upon either citizenship or country of birth (Höglund 2002, 403-407). In this literature review the term immigrant will refer to citizenship; although persons with a foreign citizenship did become Swedish citizens 1945-1975, they were relatively few. During this period being an immigrant was almost synonymous with having a non-Swedish citizenship.

In the social sciences integration, in its simplest form, means a process which leads to a merging of different entities; integration is the result of this process. In a deeper sense, integration is about the cohesion in society and the participation and involve- 
ment by minorities in the economy, production, distribution of resources, politics and government of the majority's societal structure (Westin 1999). Alas, integration is given a very wide definition in the public debate, meaning everything from a utopian state of egalitarianism to the absence of segregation; the most common definition of integration in the public debate refers to a process leading immigrants to become a part of the country of destination (Björklund 2007, 61).

Spatial integration may be the opposite of segregation, whereas social integration is about civic rights and participation/involvement in community life; economic integration is about equal access to the labour market regardless of ethnic grouping, while cultural integration is about the mutual respect for each other's cultures and traditions by different groups in society (Popoola 2002, 13-15). During the post-war era integration of marginal groups in the Swedish society - women, children, elderly, disabled and persons with social problems - has been a corner stone in the formation of the Swedish welfare society. The policy goal has been to integrate them into society and on the labour market (Olsson Hort 1992, 60, 67).

Höglund (2002, 409-12) discusses the ideologies and values underlying different definitions of socio-cultural differences between ethnical groups and how these differences have developed over time. It is a challenging task to construct a definition of e.g. integration without long discussions on the underlying ideologies and values as well as discussing different theoretical schools. A second challenging task is to quantify integration - have immigrants moved towards the natives or vice versa if we find that the differences have narrowed over time? To determine such questions are beyond the scope of this literature review; if the differenced have increased or increased is of interest here, but not who caused the changes. Consequently, a very simple definition of integration will be used here: Significant differences between immigrants and the natives will be deemed to illustrate a lack of integration in respect of immigrants whereas no or marginal differences will be deemed as evidence of the fact that immigrants have been integrated.

\section{An analytical framework}

A set of nine variables will be analysed in order to examine whether the immigrants to Sweden 1945-1975 were integrated or not. Since the working hypothesis in this paper answers the question with yes - the earlier immigrants were integrated - it is possible to construct sub-hypotheses for each and every of the nine variables. The selected variables follow the analytical scheme used by Statistics Sweden when analysing integration of immigrants in the 1990s and 2000s (Vogel et al. 2002).

1. Relative employment rates - if immigrants were integrated at the labour market the relative employment rates should only show small or insignificant difference between native and immigrated labour. 
2. Relative unemployment rates - if immigrants were integrated at the labour market the relative unemployment rates should only show small or insignificant difference between native and immigrated labour.

3. Relative incomes - if immigrants were integrated at the labour market the relative incomes should only show small or insignificant differences between native and immigrated labour.

4. Occupational structure - if immigrants were integrated at the labour market the occupational structure should only show small or insignificant difference between native and immigrated labour.

5. Work environment - if immigrants were integrated at the labour market the relative work environment should only show small or insignificant difference between native and immigrated labour.

6. Poor relief - if immigrants were integrated at the labour market the relative need for poor relief should only show small or insignificant difference between native and immigrated labour.

7. Housing - if immigrants were integrated at the labour market the material standard and housing should only show small or insignificant difference between native and immigrated labour.

8. Political resources - The political resources analysed here will only focus on activities related to labour unions and political parties. If immigrants were politically integrated only small or insignificant difference between native and immigrated labour will be found regarding political enrolment and participation rates in the general elections. Immigrants will thus not have the same political resources as natives, partly due to the fact that they are not allowed to vote in the election since they are foreigners.

9. Social networks - if immigrants were integrated they will only show small or insignificant difference between native and immigrated labour when it comes to social networks. At the same time, being a newcomer, however, means limited social network; due to distance immigrants can be assumed to have less direct contacts with their family than natives; language inabilities may eventually reduce social interaction with native neighbours and work colleagues.

\section{Immigration after World War II}

Sweden has been an immigration country since the 1930s and the share of foreign-born persons increased from a very low level to over 12 percent of the population in 2005 (SCB 2006). The reasons for immigration to enter and stay in Sweden have changed as well as the immigration categories. Until the end of 1960s, Swedish industry was 
in need of labour, and as a response to this a common Nordic labour market was introduced in 1954. The immigration from Denmark, and Norway and, especially, Finland was large during this time. A significant immigration also took place from Southern Europe (Italy, Yugoslavia, Greece and Turkey) and it was primarily unskilled labour that was demanded (Lund and Ohlsson 1994a, 71-, 140).

During this era of labour immigration an immigration of refugees to Sweden also took place. In comparison to the labour immigration the number of refugees was modest. Between 1945 and 1947 approximately 35.000 refugees arrived to Sweden (Norborg 1988, 273; Hadenius 1987, 50; Lundh and Ohlsson 1994a, 34). About 7.000 refugees from Hungary arrived to Sweden 1956-1960 and about 3.000 Czechoslovakians arrived 1968-1970 (Lundh and Ohlsson 1994a, 34-). During 1968-1972 about 2.500 Jews escaped an increasing anti-Semitism in Poland to become refugees in Sweden (Svanberg and Tydén 1992, 332). In the early 1970s the immigration changed. The period between 1970 and 1985 can be seen as a transitional phase from labour immigration to refugee and family immigration (Lund and Ohlsson 1994a, 23).

The era of labour immigration in Sweden is related to the economic boom, industrial expansion and the creation of the welfare state. Many immigrants choose Sweden because of the good possibilities to get a job during this period; in 1971-72 the economic situation in Sweden significantly lowered the demand for labour and in the mid-1970s the non-Nordic labour immigration had ceased (Lundh 2005, 23-, 31-).

\section{Relative employment}

Ekberg and Gustafsson $(1995,34)$ stresses that immigrants had higher employment rates than the natives during the 1950s and 1960. They explain this with long working hours for the immigrant population in the labour force, and especially the high employment rates for immigrant women relative native women. A similar explanation is given by Ekberg and Andersson $(1995,52)$. Furthermore, Lundh $(2005,62)$ explains the higher employment rates for immigrants with a more favourable the age-structure, i.e. the immigrants were younger than the native population. In table 1 the higher employment rates for immigrants are shown; the native population is given the index value 100 .

Arnstberg and Ehn $(1976,131)$ find in their interview study that for several immigrant groups it was common to have one job during the day and one in the evening, which is confirmed in the study by Lundh $(2005,62)$. Also Wadensjö's $(1973,187)$ pioneering study is based on interviews. He finds that immigrants from Finland, Italy, Yugoslavia and West Germany have higher employment rates than natives in the same age. In the study by Arnstberg and Ehn $(1976,131)$ especially the Turks have more than one job. 
Table 1. Relative employment rates for foreign born persons in Sweden 1950-1975. Age-standardised values. Index. Natives $=100$.

\begin{tabular}{llll}
\hline & Male & Female & Total \\
\hline 1950 & n/a & n/a & 120 \\
1960 & 100 & 110 & 104 \\
1967 & $\mathrm{n} / \mathrm{a}$ & $\mathrm{n} / \mathrm{a}$ & 110 \\
1975 & 98 & 102 & 100 \\
\hline
\end{tabular}

Source: Ekberg (2006)

It appears to be a consensus in the previous research that immigrants worked long hours and often had more than one job. We must, however, bear in mind that these results are based upon interviews; quantitative evidence on more than one job and long working hours is missing for immigrants in the 1950s and 1960s.

For the immigrants who came in the late 1960s and early 1970s the situation at the labour market had changed significantly due to the structural change in the economy. Lundh and Ohlsson (1994b, 100) described the labour market situation for the immigrants in the following way: "Five years after residential registration with local authorities only one half had any sort of regular employment at all, 40 percent were undergoing some form of training and 10 percent were sick or unemployed".

\section{Relative unemployment}

The immigrants were overrepresented in professions characterised by high unemployment in the 1960s, according to Wadensjö $(1973,187)$. In another study he finds that immigrants have been overrepresented since the end of the 1940s until the 1970s in professions with high risks for unemployment (Wadensjö 1976b, 117). A similar result is found in another study covering the period 1967-1973 (Wadensjö 1981, 102). Ekberg and Gustafsson $(1995,40)$ also support the finings that the unemployment rates for immigrants were higher than for the natives before 1970. Lundh and Ohlsson (1994a, 81) found rising unemployment rates for immigrants than for natives in the mid-1960s and, furthermore, immigrants in general had higher unemployment rates than natives. This is also concluded by Lundqvist $(2002,116)$.

\section{Relative incomes and wages}

Wadensjö $(1973,187)$ finds the immigrants overrepresented in occupations with low median wages. There are also significant gender differences in the relative income structure between immigrants and natives. "Among the blue-collar immigrants, who for the most part come from Finland and Southern Europe, the man has, on average, a lower income than the native Swede. On the other hand, immigrant women from 
these countries have a higher average annual income than Swedish women. This is primarily because of the longer working hours of the immigrant women", Ekberg $(1983,328)$ concludes. In a later study by Ekberg $(2006,148)$ he found that the relative income for all immigrants were 122 percent of the natives' in 1967, but sunk to 99 percent in 1978. The higher relative income by immigrant women is explained by higher employment rates, according to Ohlsson $(1975,142)$.

In a study by Ohlsson $(1978,55)$ on the non-Nordic immigrants' incomes in the city of Malmö 1948-1967, the results showed that the incomes of these immigrants were below the incomes of the native Swedes. The relative incomes of the non-Nordic white-collar workers were 96 percent compared to the incomes of the native whitecollar workers in 1948 and 86 percent for the blue-collar workers. In 1958 the relative incomes for white-collar workers had sunk to 92 percent while the relative incomes for blue-collar worker had rose to 95 percent. These levels had changed significantly in 1967; for white-collar workers the relative incomes were 76 percent and 86 percent for blue-collar workers. Ekberg and Gustafsson $(1995,34,55)$ and Ekberg and Andersson $(1995,52)$ explain the higher relative incomes of immigrants compared to the natives' while immigrants, at the same time, had lower relative wages during the post war era up to the 1970 s by long working hours and a high employment rate for immigrant women.

Later studies show that several immigrant groups (e.g. Germans, Norwegians, Americans and Czechs) had higher mean annual incomes than the Sweden in 1970; in 1990 none of the immigrant groups had higher incomes than the natives (Scott 1999, 124).

\section{Occupational structure}

According to Ekberg (1983) the occupational structure of foreign citizens differs significantly from the natives' occupational structure; foreign citizens are significantly overrepresented in manufacturing and in service jobs. Among the service jobs immigrants are concentrated to restaurant jobs and industrial cleaning. Wadensjö (1976b, 117) argue that the immigrants took the hard and dirty jobs with high injury risks the natives did not want to have.

Due to better possibilities for higher studies the Swedish youngsters have chosen education and better, non-industrial work. In the 1950s this was especially pronounced in typical female jobs - the young Swedish females rejected jobs as maids and housekeepers in favour for better paid jobs. This opened up for a large immigration of women from Finland and Germany to fill the vacancies (Wadensjö 1981, 97). Both Gunhild Kyle $(1979,200)$ and Paulina de los Reyes $(2002,66)$ argue that the immigrant women did the housekeeping for the Swedish women when they picked up work outside the household. 
Table 2. The occupation of the labour force by sex. sector and origin 1950.

\begin{tabular}{lrcrc}
\hline 1950 & \multicolumn{2}{c}{ Male } & \multicolumn{2}{c}{ Female } \\
\hline & \multicolumn{1}{c}{ All } & Foreigners & \multicolumn{1}{c}{ All } & Foreigners \\
\cline { 2 - 5 } Agriculture and forestry & 25.3 & 11.1 & 6.4 & 1.8 \\
Mining & 0.7 & 0.9 & 0 & 0 \\
Manufacturing & 45.6 & 60.4 & 25.9 & 38.3 \\
Transport & 9.1 & 4.9 & 5.2 & 2.2 \\
Commerce & 10.2 & 13.1 & 28 & 20.3 \\
Public services & 8.4 & 8.3 & 22.6 & 19.5 \\
Domestic work & 0 & 0 & 11 & 16.4 \\
Unspecified & 0.7 & 1.3 & 0.8 & 1.5 \\
Total & 100 & 100 & 99.9 & 100 \\
\hline
\end{tabular}

Source: SOS Folkräkningen 1950 Vol. VI

Table 3. The occupation of the labour force by sex. sector and origin 1960.

\begin{tabular}{lrcrc}
\hline 1960 & \multicolumn{2}{c}{ Male } & \multicolumn{2}{c}{ Female } \\
\hline & All & foreigners & All & foreigners \\
\cline { 2 - 5 } Agriculture and forestry & 17.9 & 7.8 & 4 & 1.4 \\
Mining & 1 & 1.7 & 0.1 & 0.2 \\
Manufacturing & 37.8 & 56.6 & 25.6 & 43.9 \\
Construction & 12.5 & 7.6 & 1 & 0.4 \\
Electricity. gas. water & 1.4 & 0.6 & 0.3 & 0 \\
Transport & 8.7 & 4.7 & 4.5 & 1.4 \\
Commerce & 10 & 7.4 & 21.7 & 9.9 \\
Public services & 10.2 & 12.9 & 35.2 & 28.2 \\
Domestic work & 0 & 0 & 7.2 & 13.8 \\
Unspecified & 0.3 & 0.7 & 0.3 & 0.6 \\
Total & 99.8 & 100 & 99.9 & 99.8 \\
\hline
\end{tabular}

Source: SOS Folkräkningen 1960 Vol. IX and X

The occupational structure for immigrants and the total population in 1950 and 1960 is shown in tables 2 and 3. According to the censuses 1950 and 1960 both male and female immigrants were significantly overrepresented in the manufacturing sector; Female immigrants were overrepresented in domestic work in 1950 and male immigrants were overrepresented in the mining sector in 1960. Immigrants were also significantly underrepresented in the agriculture and transport sectors in both censuses. In 1950 immigrant women were underrepresented in the commerce sector and in 1960 in the commerce and public services sectors. 
Table 4. The occupation of the labour force by sex. sector and origin 1966/67.

\begin{tabular}{lrcrc}
\hline 1966/1967 & \multicolumn{2}{c}{ Male } & \multicolumn{2}{c}{ Female } \\
\hline & All $^{*}$ & Foreigners $^{* *}$ & All $^{*}$ & Foreigners $^{* *}$ \\
Agriculture+forestry+fishing & 12.8 & 0.6 & 8.6 & 0.0 \\
Mining+manufacturing & 36.4 & 60.9 & 21.4 & 51.4 \\
Construction & 15.3 & 4.6 & 1.2 & 0.0 \\
Electricity/gas/water & 1.4 & 1.3 & 0.3 & 0.0 \\
Commerce+financial & 12.1 & 12.4 & 22.0 & 17.5 \\
Transport & 9.0 & 5.0 & 4.1 & 5.0 \\
Public service + admin & 13.1 & 15.1 & 42.3 & 26.1 \\
Total & 100.1 & 99.9 & 99.9 & 100.0 \\
\hline
\end{tabular}

* 1966 - source: SM Am10 P3/7

** 1967 - source: Ohlsson (1978)

The 1965 census does not contain any information on immigrants. The study by Ohlsson (1978) for 1967 can be supplemented to the census, which is done in table 4. Immigrants, both male and female, are significantly overrepresented in the mining and manufacturing sector while significantly underrepresented in the agriculture sector. Immigrant women are also significantly underrepresented relative the total number of women working the sectors commerce and finance as well as public services and administration.

Table 5. The occupation of the labour force by sex. sector and origin 1975.

\begin{tabular}{lrrrr}
\hline 1975 & \multicolumn{2}{c}{ Male } & \multicolumn{2}{c}{ Female } \\
\hline & \multicolumn{1}{c}{ All } & Foreigners & All & Foreigners \\
\cline { 2 - 5 } Agriculture & 9.1 & 2 & 5.1 & 0.1 \\
Mining + Manufacturing & 38.3 & 70.6 & 18.7 & 46.4 \\
Construction & 11.7 & 6 & 1.5 & 0.8 \\
Commerce+trade & 10.5 & 5.2 & 16.3 & 10.7 \\
Transport. mail. telecom etc & 8.6 & 4.8 & 4 & 2.2 \\
Public administration & 5.2 & 0.8 & 4 & 0.8 \\
Education. medical care etc & 7.5 & 4.9 & 38.3 & 25.9 \\
Other & 9.1 & 5.8 & 11.9 & 12.4 \\
Total & 100 & 100.1 & 99.8 & 99.3 \\
\hline
\end{tabular}

Source: SCB (1975)

In 1975 both male and female immigrants are significantly overrepresented in the mining and manufacturing sector, and with one exception they are underrepresented in all other sectors. The exception concerns women working in the sector "other"; here the immigrant women are slightly overrepresented. 
It was not only labour immigrants who came to fill the vacancies in the Swedish industry. The Swedish industry employed refugees immediately after the WW2 and most of them came from Poland and the Baltic countries. No matter what profession they have had in their country of origin, they were sent to work in the Swedish industry (Svanberg and Tydén 1992, 326-). Unfortunately, working in the industry did not serve as a transitional work to the Swedish labour market and better jobs; most of the refugees got stuck in that sector (Ohlsson 1978, 183-).

\section{Work environment and health}

In a study analysing the immigrants to Sweden 1940-1970 the following conclusion is made: "Migrants are highly occupationally segregated from the rest of the population. They are concentrated in occupations with relatively bad working conditions as measured by the industrial injury rates of the different occupations" (Wadensjö 1976a, 9). Similar findings were made in Wadensjö (1976b, 117). Another study by Wadensjö $(1981,100)$ showed that the injury rate at work 1966-1970 was 50\% higher for immigrant men than for native men and $115 \%$ higher for immigrant women than for native women.

In a report on the living conditions of the immigrants in 1975, made by Statistics Sweden, it was concluded that "in general, foreign citizens have a worse working environment compared to the Swedish population. They are 2-3 times more exposed to permanent and deafening noise, and they have more often dirty jobs with high risks of work injuries. Foreigners also work with repetitive and biased body moves, and become sweaty daily by all-out effort more often than natives. They have often jobs that are more stressful and monotonous than natives, and they have few possibilities of learning new things or get training in their job" (SCB 1975, 98).

\section{Poor relief ${ }^{2}$}

The National Board of Social Welfare (Socialstyrelsen) made a special survey in 1950-52 on the recipients of poor relief by nationality; the official statistics started to collect information on recipients of poor relief by nationality in 1964, which means that the knowledge on how dependent foreign citizens were of poor relief in Sweden is limited prior to that. The available data shows that foreign citizens were overrepresented amongst the households receiving poor relief during the period 1950-1975 (table 6).

As indicated in table 6, the share of foreigners among the recipients of poor relief was abow the share of the recipients of poor relief for the total population in the beginning of the 1950s and beginning of 1960s. In 1964 the share of foreigners among the

2 Today the term "economic assistance" has replaced "poor relief". The term poor relief is used here because it was the used term during the analysed period of this literature review. 
recipients of poor relief was about twice as high as for the total population; in 1975 it was almost three times as high! Lundh and Ohlsson (1994a, 65) argue that the share of foreign citizens among the recipients of poor relief was lower than for the natives in 1958 , but they do not produce any references to support this information.

Table 6. The share of foreign households in Sweden with poor relief and the total share of households with poor relief in Sweden 1950-1975. Percentage.

\begin{tabular}{lccccc}
\hline & 1950 & 1958 & 1964 & 1970 & 1975 \\
\hline Foreign citizens & $5.2^{*}$ & $3.5^{* *}$ & 4.9 & 12.2 & 14.7 \\
Total population & 4.2 & 4.4 & 2.5 & 5.1 & 5.2 \\
\hline
\end{tabular}

* 79 percent of the recipients of poor relief who were foreign citizens were non-Scandinavians in 1950

** Lundh and Ohlsson (1994:65) do not give any reference to this figure.

Source: Socialstyrelsen (1952). SOS Socialhjälp. SOS Socialvård and Lundh and Ohlsson (1994)

Then surveys of the Nations Board of Social Welfare also show that there were large differences in the need of poor relief of foreign citizens. Danish citizens were hardly in need of poor relief (ca 2 percent), and Finnish and Norwegian citizens did not need poor relief to any large extent ( $4-5$ percent). The share of non-Scandinavians dependent on poor relief in the early 1950 s, reaching almost 80 percent of the foreigners, indicates that non-Scandinavian immigrants at this time had a significantly different economic situation than Nordic immigrants and the native population (Socialstyrelsen 1952, $260 ; 1953,697 ; 1954,641)$. Unfortunately, the knowledge of the need for poor relief by nationality is very limited indeed for the period 1945-1963, which means that we can only speculate on the causes of the significant differences shown in table 6 .

\section{Housing}

It was more common that immigrants lived in apartments than native Swedes in the 1950s and 1960s; it is more common that native Swedes live in houses and townhouses than immigrants. Furthermore, the immigrants are significantly overrepresented amongst those who have lodging as accommodation. The findings show that immigrants are overrepresented in the old and worn-down housing stock as well as in the newly built housing stock. ${ }^{3}$ Especially Yugoslavians, but also Finns and Italians, lived in old and worn-down apartments compared to native Swedes and Germans; the same pattern is found regarding restriction for space and overcrowding. A smaller share of the household incomes for Finns, Italians and Yugoslavians are used on housing

3 The newly built housing stock refers to the housing programme "Miljonprogrammet" which aimed at building 1 million new apartments in the late 1960s to mid-1970s. Usually these apartments were built in the suburban areas of the major industrial towns in Sweden. 
compared to native Swedes and Germans, which probably can be explained by the lower standard of the housing. For modern housing the immigrants pay more as they live in newly build apartments with high rents (Wadensjö 1973, 202, 297-). It was very common that immigrants lived in the old and worn-down housing stock before 1965. Between 1965 and 19751 million new apartments were built and these areas were quickly filled with newly arrived immigrants (RTK 1985, 33).

That a majority of immigrants lived as tenants in apartments and not bought a house themselves can be explained by the fact that foreigners were not allowed to own property in Sweden at this time without a special permit. A second explanation may be that the immigrants had plans to return to where they came from and did not want to invest their savings in fixed capital; if they returned they had to wait until the house was sold (Häggström et al. 1990, 200).

Housing segregation between immigrants and natives is nothing new. The Italians who came to Stockholm, Västerås, Göteborg and Malmö in the 1950s, i.e. the major industrial towns, settled down in neighbourhoods with many Italians (Svanberg and Tydén 1992, $329,331)$. The same tendency is found for other immigrant groups in the 1960s - e.g. Finns and Yugoslavians - they clustered to their fellow countrymen (Olsson Hort 1992, 98). So did the Turks and Greeks (Arnstberg and Ehn 1976, 126, 130-).

A related aspect to housing regards settlement restrictions. All major refugee groups to Sweden at this time - mostly of Baltic, Polish and Soviet origin - faced settlement restrictions, i.e. they were not allowed to settle down in the cities of Stockholm, Göteborg and Malmö (Svanberg and Tydén 1992, 316-; De Geer 1991, 10).

In an analysis of the development of the coefficient of variation (C.V.), that can be seen as an indicator for the settlement diffusion, Johansson and Rauhut $(2008,48)$ show that the accumulated number of foreign born persons (stock) in the Swedish regions, likewise the number of immigrants (flow), has became more evenly distributed during the period 1950-2005 (see table 7). The lower coefficients of variation are, the more even is the diffusion of immigrants.

Table 7. Coefficient of Variation (C.V.) for the stock and flow of immigrants to Sweden 1950-2005 for all regions $(\mathrm{N}=21)$ and non-metropolitan regions $(\mathrm{N}=18)$.

\begin{tabular}{lcccc}
\hline & \multicolumn{2}{c}{ Stock of immigrants } & \multicolumn{2}{c}{ Flow of immigrants } \\
\hline & C.V. $(\mathrm{N}=21)$ & C.V. $(\mathrm{N}=18)$ & C.V. $(\mathrm{N}=21)$ & C.V. $(\mathrm{N}=18)$ \\
\cline { 2 - 5 } 1950 & 0.600 & 0.636 & 0.869 & 0.946 \\
1967 & 0.600 & 0.540 & 0.492 & 0.435 \\
1975 & 0.563 & 0.558 & 0.526 & 0.548 \\
1990 & 0.416 & 0.359 & 0.249 & 0.257 \\
2005 & 0.370 & 0.314 & 0.285 & 0.196 \\
\hline
\end{tabular}

Source: Johansson \& Rauhut 2008:48. 
According to Johansson and Rauhut (2008, 43-47) the three metropolitan regions have always attracted a majority of all immigrants, but the distribution of immigrants between the remaining counties in Sweden has become more even between 1950 and 2005. The traditional industrial regions were overrepresented among the immigrants up to the middle of the 1970s. The transformation of the economy with deindustrialisation and the rise of the knowledge-based economy have reduced the importance of the labour market variables for all kind of immigrants concerning the initial settlement pattern. Instead, the most important pull-factor has been and still is the regional distribution of foreign-born people and the initial settlement pattern (Rauhut and Johansson 2008, 2010).

\section{Political resources}

Peterson et al. (1998, 92-94) mark out that immigrants have no rights to vote in the general elections for the parliament, but in the local elections; naturalised Swedish citizens thus have that right. The analysis covers the period 1987-1997 and the conclusion is that immigrants are outside the democratic institutions in Sweden. They have a significantly lower participation rate in the local elections than natives, they have a significantly lower activity rate in political parties and manifestations than natives and they do less to exercise their potential political influence compared to natives. Petersson et al. (1998, 94) argue that the gap between natives and immigrants is increasing and that immigrants are about to become political outsiders. When the immigrants were given the right to participate in the local elections in 1976, the participation rate was about 60 percent; in the recent elections the it was down to 35 percent (Ekberg 2006, 146).

As immigrants were not allowed to participate in the representative democracy at all before the 1976 elections they did not have the possibility to make their voices heard through the ballot. Hence, they have had limited political resources before 1976. Exercising one's political rights can be done by other means than through the ballot in a democracy. Participating in political organisations, e.g. political parties and trade unions, is also a mean to express ones political voice.

In a survey done by the Swedish Confederation of Trade Unions (LO) to its members in 1951 the result showed that immigrant labour was looked upon with suspicion. The reason was that the immigrants did not enrol in trade union activities as native labour did. Furthermore, the immigrated labour had other and different trade union culture, e.g. individualism was accepted. As a consequence, immigrants were considered to neglect the trade unions and the political solidarity of workers (Lundqvist 2002, 119-121). This view on immigrant labour remained in the 1960s in the trade unions and active measures were taken to enrol immigrant labour in the trade unions (Lundh 1994, 30). The political strength of the trade unions rested upon the intimate link to the Social democratic party, a high trade union enrolment rate and full employment required loyal and devoted members (Lundqvist 2002, 120-). 
Immigrants had restricted political rights before 1976 - they were not allowed to vote at all in the elections, nor could they be elected for political positions. Lundh (1994, 29) mentions that immigrants were not allowed to work in the government sector in the 1950s and 1960s, but today that restriction applies only to higher (political) posts today (Ekberg 2006, 146). If the immigrant labour shared the political values of the trade unions they had the possibility to exercise political influence through them; immigrants with other political preferences had few means to express their political voice.

\section{Social networks}

Many of the immigrants who came from Yugoslavia, Turkey and Greece in the 1960s had difficulties to adjust into the Swedish society, mainly due to socio-cultural differences. One of the main reasons were that the immigrants came from rural and agricultural areas in their home countries; in Sweden they picked up unqualified jobs in industry and most of them settled down in industrial towns and metropolitan areas. In the mid-1960s the public opinion on immigration changed in Sweden - from positive to negative - due to the lack of integration (Svanberg and Tydén 1992, 331). The Yugoslavians, Greeks and Turks had little social contact with the Swedes. There were also conflicts between the Yugoslavian immigrants due to ethnicity (Arnstberg and Ehn 1976, 126).

Furthermore, the view on e.g. women and raising children were very different from what was socially acceptable in Sweden, which made it difficult for many of these immigrant groups to get in touch with Swedes. Another obstacle for socialising with Swedes were that a majority of the colleagues they worked with also were immigrants, which led to a poor knowledge in the Swedish language (Lundh 1994, 30; Arnstberg and Ehn 1976, 108-133).

Immigrants have less close contacts to neighbours and persons in their neighbourhood than natives Swedes. About 60 percent of the native Swedes talk to their neighbours frequently while only about 30 percent of the immigrants do so. There are however differences within the immigrant population: about 34 percent of the Finns talk frequently with their neighbours, but only 23 percent of the immigrants from Southern Europe do the same (SCB 1975, 48-).

\section{Integrated or not?}

The discussion on relative employment showed that many immigrants had more than one job. Simultaneously, the relative unemployment rate for immigrants was higher than for natives during the studied period. It is difficult to consider the immigrants to be integrated at the labour market when such unemployment gap. In the section on

4 General Directors and judges need to be Swedish citizens as well as positions in the defence forces. The latter are. however. not political positions. 
the occupational structure of immigrants it was very obvious indeed that significant labour market segregation existed. The immigrants took the dirty, dangerous and degrading jobs the natives did not want to have, which resulted in injury rates for different occupations.

Although the immigrants show higher relative incomes than the natives, their relative wages were below the natives. The higher relative incomes, for both men and women, can be explained by the fact that many immigrants had more than just one job. The low relative wages do not indicate integration.

Already in the 1950s the immigrants were more dependent on poor relief than the total population; in the 1960s this has not changed. To be dependent on poor relief means that the household's potential to generate the needed money for survival is limited. In general, when this occurs, the causes are found in low incomes, often related to unemployment and sickness. This study has not proved such relationship. Nevertheless, that immigrants have been overrepresented amongst the population in need of poor relief indicate a marginal position in society and it is difficult to claim that immigrants were integrated in terms of incomes when they are overrepresented among the recipients of poor relief.

Immigrants had a lower standard of living than natives regarding housing. Overcrowded accommodation and restrictions in space were also more common for immigrants than natives at this time. Again, this does not indicate integration at the housing market.

Since natives and immigrants seldom worked together it was difficult to make friends with each other. Immigrants made friends with other immigrants. This does not indicate integration concerning social networks.

Regarding the political resources of immigrants after the World War II up to 1975, they were basically non-existing. They were not allowed to vote in the local and regional elections, they were not allowed to be elected to a political post. They could, however, enrol themselves in the trade union activities, but the trade unions looked upon them with suspicion. Today non-Swedish citizens are allowed to vote in the local and regional elections as long as they are registered citizens of the community; they are allowed to be appointed to political posts locally and regionally. Although the participation rates of immigrants are low in the local and regional elections they have at least been given some important political resource which they can utilise if they want. Contrary to former times, some members of the Swedish parliament are naturalised Swedish citizens. Even if it is difficult to conclude that immigrants are politically integrated today, improvements have actually been made. 


\section{Concluding remarks}

Although tentative and explorative in its character, this study indicate that immigrants to Sweden were far from as integrated in former times as is commonly believed. Instead, immigrants and natives worked in different sectors in the economy; this labour market segregation resulted in higher unemployment, lower wages and higher injury rates for immigrants than natives. Immigrants also experienced a lower standard of living than natives. A consequence of a segregated labour market and a segregated housing market was that immigrants and natives had relatively limited possibilities to make friends and create social networks with each other. Refugees faced settlement restrictions and foreigners were not allowed to own property without special permits. Finally, immigrants did not have much of political resources in Sweden 1945-1975. There are few indications of immigrants being successfully integrated into the Swedish society during this period.

The period 1945-1975 was dominated by labour immigration while today's immigration to Sweden is dominated by tied-movers to previous immigrants, most of them refugees. A second major difference is that the immigrants to Sweden 1945-1975 originated, more or less, from European countries, which is not the case today. A comparison of the integration of immigrants in former times with today's integration must take the changed immigration causes into account otherwise the result will be biased. One could expect labour immigrants to be better integrated than refugees. This is however not indicated by the results in this literature review.

This study does not allow any sharp conclusions on whether immigrants were better integrated into the Swedish society in former times, only some indications. The development of the integration of immigrants to Sweden has not been a transition from good to bad, but rather from bad to worse. To what extent this can be interpreted as immigrants were better integrated in former times than today or not can thus be discussed. In either case, much more research is needed to fill the knowledge gap(s) this study has indicated.

\section{Acknowledgements}

The author is indebted to the anonymous referees of this journal as well as Elli Heikkilä and Svante Lingärde for constructive and useful comments on an earlier version of this paper.

\section{References}

Andersson, Roger. 2000. Etnisk och socioekonomisk segregation i Sverige 1990-1998. In: Välfärdens förutsättningar-Arbetsmarknad, demografi och segregation, edited by Johan Frizell. Stockholm: Fritzes förlag.

Arnstberg, Karl-Olov and Billy Ehn. 1976. Etniska minoriteter i Sverige förr och nu. Lund: Liber Läromedel.

Åslund, Olof, Robert Erikson, Oskar Nordström Skans and Anna Sjögren. 2006. Frittinträde? Ungdomars och invandrares väg till det första arbetet. Mölnlycke: SNS förlag. 
Björklund, Anders, Per-Gunnar Edebalk, Rolf Ohlsson and Lars Söderström. 1998. Välfärdspolitik $i$ kristid - håller arbetslinjen? Kristianstad: SNS förlag.

Björklund, Hanna. 2007. Samverkan för integration. In: Vägen till Sverige, edited by Daniel Rauhut. Stockholm stad: Stadsledningskontoret.

Dahlberg, Matz, Karin Edmark, Jörgen Hansen and Eva Mörk. 2008. Fattigdom $i$ folkhemmet. Mölnlycke: SNS förlag.

De Geer, Erik. 1991. Balts in Sweden. Regional Distribution 1950 and 1989.

Paper presented at the 11the Conference on Baltic Studies in Scandinavia, June 13-16, 1991, Stockholm.

de los Reyes, Paulina (2002) Vem tar hand om barnen? Könsuppdelning och offentlig barnomsorg ur ett ekonomisk-historiskt perspektiv. In: Omvandlingens sekel. Perspektiv på ekonomi och samhälle i 1900-talets Sverige, edited by Lena Andersson-Skog och Olle Krantz. Lund: Studentlitteratur.

Ekberg, Jan. 1983. Inkomsteffekter av invandring. Växjö: Acta Wexionensia.

Ekberg, Jan. 2006. Invandring - en av vår tids stora frågor. In: Den problematiska tryggheten, edited by Bo Södersten. Mölnlycke: SNS förlag.

Ekberg, Jan and Lars Andersson. 1995. Invandring, sysselsättning och ekonomiska effekter. Stockholm: Fritzes förlag.

Ekberg, Jan and Björn Gustafsson. 1995. Invandrare på arbetsmarknaden. Kristianstad: SNS förlag.

Franzén, Eva. 2004. Invandrare och socialbidragsmottagare - ett li i ofärd. In: Egenförsörjning eller bidragsförsörjning? Invandrarna, arbetsmarknaden och välfärdsstaten, edited by Jan Ekberg. Stockholm: Fritzes förlag.

Gustafsson, Björn and Torun Österberg. 2004. Ursprung och förtidspension. In: Egenförsörjning eller bidragsförsörjning? Invandrarna, arbetsmarknaden och välfärdsstaten, edited by Jan Ekberg. Stockholm: Fritzes förlag.

Hadenius, Stig. 1987. Svensk politik under 1900-talet. Kristianstad: Tidens förlag.

Häggström, Nils, Lars-Erik Borgegård and Annette Rosengren. 1990. När finländarna kom. Migrationen Finland-Sverige efter andra världskriget. Uppsala: Statens Institut för Byggnadsforskning, Umeå universitet and Nordiska museet.

Häll, Lars. 1998. Invandrarnas levnadsförhållanden. In: Välfärd och ojämlikhet $i$ 20-årsperspektiv 1975-1995, edited by Joachim Vogel and Lars Häll. Örebro: Statistiska centralbyrån.

Höglund, Sten. 2002. Invandrarna och arbetsmarknaden. In: Arbetslivet, edited by Lars H. Hansen and Pal Orban, pp. 401-435. Lund: Studentlitteratur.

Johansson, Mats and Daniel Rauhut. 2008. Invandrarnas bosättningsmönster i ett regionalt perspektiv 1950-2005. In: Stadsregioners utvecklingskraft-trender och nya perspektiv, edited by Göran Cars and Carl-Johan Engström, pp. 39-44. Stockholm: $\mathrm{KTH}$.

Kyle, Gunhild. 1979. Gästarbeterska i manssamhället. Studier om industriarbetande kvinnors villkor i Sverige. Stockholm: Liber förlag.

Lundh, Christer. 1994. Invandrarna i den svenska modellen - hot eller reserv? Arbetarhistoria, $\mathrm{Nr}$ 2:23-36. 
Lundh, Christer. 2005. Invandringen till Sverige. Avesta: SNS förlag.

Lundh, Christer and RolfOhlsson. 1994a. Från arbetskraftsimport till flyktinginvandring. Kristianstad: SNS förlag.

Lundh, Christer and Rolf Ohlsson. 1994b. Immigration and Economic Change. In: Population, Economy and Welfare in Sweden, edited by Tommy Bengtsson. Germany: Springer Verlag.

Lundh, Christer, Li Bennich-Björkman, RolfOhlsson, Peder J. Pedersen and Dan-Olof Rooth. 2002. Arbete? Var god dröj! Invandrarna i välfärdssamhället. Kristianstad: SNS förlag.

Lundqvist, Torbjörn. 2002. Arbetskraftsinvandringen och facket. In: Befolkning och välfärd, edited by Bo Malmberg and Lena Sommestad. Stockholm: Institutet för framtidsstudier.

Molina, Irene. 2000. Etnisk boendesegregation. In: Den gömda krisen. Bjärnum: Agora.

Norborg, Lars-Arne. 1988. Sveriges historia under 1800- och 1900-talen. Stockholm: Esselte Studium.

Ohlsson, Rolf. 1975. Invandrarna på arbetsmarknaden. Lund: Ekonomisk-historiska föreningen.

Ohlsson, Rolf. 1978. Ekonomisk strukturförändring och invandring. Kristianstad: Gleerups förlag.

Olsson Hort, Sven E. 1992. Segregation - ett svenskt dilemma? Stockholm: Allmänna Förlaget.

Petersson, Olof, Jörgen Hermansson, Michele Micheletti, Jan Teorell and Anders Westholm. 1998. Demokrati och medborgarskap. Demokratirådets rapport 1998. Kristianstad: SNS förlag.

Popoola, Margareta. 2002. Integration, en samtidsspegling. Stockholm: Svenska Kommunförbundet.

Rauhut, Daniel and Mats Johansson. 2008. The Regional Distribution of Immigrants to Sweden 1967-2005. Regionale Trender 2008(1):19-27.

Rauhut, Daniel and Mats Johansson. 2010. Regional settlement patterns for 10 immigrant groups in Sweden 1975-2005. Finnish Journal of Ethnicity and Migration, 5(1):19-28.

RTK (Regionplane- och Trafikkontoret). 1985. Invandrare i Stockholms län, Rapport 9: Bostäder och boende. Stockholm: Regionplanekontoret.

SCB (Statistiska centralbyrån). 1966. SM Am10 P3/7.

SCB (Statistiska centralbyrån). 1975. Invandrarnas levnadsförhållanden.

SCB (Statistiska centralbyrån). 2002. Integration till svensk välfärd? Om invandrares välfärd på 1990-talet. Levnadsförhållanden rapport 96.

SCB (Statistiska centralbyrån). 2004. Efterkrigstidens invandring och utvandring. Demografiska rapporter 2004:5.

SCB (Statistiska Centralbyrån). 2006. To measure and monitor internal migration based on national population register. Befolknings- och välfärdsstatistik rapport 2006:7.

Scott, Kirk. 1999. The Immigrant Experience: Changing Employment and Income Patterns in Sweden 1970-1993. Lund: Lund University Press. 
Socialdepartementet. 2001. Välfärdsbokslut för 1990-talet Slutbetänkande Kommittén Välfärdsbokslut SOU2001:79. Stockholm: Fritzes förlag.

Socialstyrelsen. 1952. Fattigvård och barnavård till utlänningar under 1950. Sociala Meddelanden 1952 (4):260.

Socialstyrelsen. 1953. Fattigvård och barnavård till utlänningar under 1951. Sociala Meddelanden 1953 (11):697.

Socialstyrelsen. 1954. Fattigvård och barnavård till utlänningar under 1952. Sociala Meddelanden 1954 (10):641.

SOS Folkräkningen 1950.

SOS Folkräkningen 1960.

SOS Socialhjälp.

SOS Socialvård.

Svanberg, Ingvar and Mattias Tydén. 1992. Tusen år av invandring. Stockholm: Gidlunds förlag.

Vogel, Joachim, Mikael Hjerm and Sven-Erik Johnasson. 2002. Integration till svensk välfärd? Om invandrares välfärd på 90-talet. Örebro: SCB and Arbetslivsinstitutet.

Wadensjö, Eskil. 1973. Immigration och samhällsekonomi. Lund: Studentlitteratur.

Wadensjö, Eskil. 1976a. Occupational Segregation of Migrant Workers in Sweden. Växjö Migration Studies No. 5.

Wadensjö, Eskil. 1976b. Invandrerlandet Sverige. Den ny verden Vol. 10 No. 3.

Wadensjö, Eskil. 1981. Arbetsmarknad, invandring och ekonomi. In: Invandringen och framtiden, edited by Eva Hamberg and Tomas Hammar. Liber förlag.

Westin, Charles. 1999. Mångfald, integration, rasism och andra ord. Stockholm: Socialstyrelsen. 